\title{
Has Japanese technology made possible quiet Soviet subs?
}

\section{Tokyo \& Washington}

Is there a direct link between the illegal export of milling machines to the Soviet Union by Toshiba Machine Co. and the appearance of quiet Soviet submarines? This question has been the subject of intense debate in the Japanese Diet during the past week, and it seems there is no simple answer.

Toshiba Machine's export of nine- and five-axis milling machine tools was a deliberate violation of COCOM rules that govern the transfer of Western technology to the Eastern bloc, and the general view in Japan is that the company should be punished. But there the consensus ends.

Foreign Minister Tadashi Kuranari declared in the Diet last week that there is a link between the illegal exports and quieter Soviet submarines. But other Diet members and military experts reject this view. They point out that quieter submarines belonging to the Victor III, Mike and Sierra classes first appeared in 1983 and early 1984 before completion of the Toshiba milling machines at the Leningrad shipyard in late 1984 . The only quiet submarines to put to sea after 1984 were those of the Akura class which are built on the eastern seaboard of the Soviet Union far from Leningrad.

Hildeo Aoki, a defence commentator, further argued on the Asabi television network that the chief factor determining the quietness of Soviet submarine propellers is their design, not milling by Toshiba machines - a view that is shared by some US antisubmarine warfare experts.

Propellers produce noise as a result of cavitation. Streams of bubbles formed at the tip of the rotating propeller blade implode with a characteristic noise when they are drawn into the high-pressure region behind the propeller. Cavitation can be reduced by decreasing the speed of propeller rotation. The past several years have seen remarkable changes in the design of Soviet propellers to this end, and the latest models have huge multiple blades, shaped like scythes, that project far out of the water when the submarine surfaces.

Aoki also pointed out that cavitation accounts for only about $20-80$ per cent of the noise made by submarines, other external sources of noise being the propeller shaft and the water-cooling system for the nuclear-powered engine (internal sources such as the turbine can be largely silenced through sound-proofing). If Soviet submarines have gone silent, other factors are involved apart from propeller design, he said.

Debate over the issue has caused con- fusion in the Japanese government. Following Kuranari's assertion of a direct link (between machine exports and quieter Soviet submarines), Prime Minister Yasuhiro Nakasone said there is only "thick suspicion" of linkage, while International Trade and Industry minister Hajime Tamura said the link was "not yet clear". Just before Tamura's visit to the United States last week, the Nakasone administration reached a unified view of "thick suspicion", although chief cabinet secretary Masabaru Gotada insisted that this unified view did not necessarily admit a link and "we will not admit a cause-and effect relationship without conclusive evidence".

Upon his return from Washington, Tamura declared that he had been shown convincing evidence by the United States that Toshiba's machines helped silence Soviet submarines. But the information was classified. James Auer, special assistant for Japanese affairs at the US Defense Department, has made similar reference to top-secret evidence. But when pressed by Japanese reports to cite specific numerical data, he could say only that Soviet submarines could previously be detected by underwater sonar at a distance of $80 \mathrm{~km}$ and this had been reduced to about $75 \mathrm{~km}$. He admitted that there are other ways to reduce noise apart from propeller modification, but insisted that the Toshiba machines have been a key factor in silencing Soviet submarines.

On the other hand, former Navy secretary John F. Lehman Jr and Admiral James D. Watkins, recently retired chief of naval operations and a submariner, have blamed the spy ring headed by former Navy radioman John A. Walker $\mathrm{J} r$ for the sudden Soviet advances.

Given the equivocal evidence that has been made public, why is the Nakasone administration so passive in its acceptance of US assertions that Toshiba's machines silenced Soviet submarines? Undoubtedly the Japanese government wants to calm the raging protectionist mood in the US Congress. But also the hullabaloo over Toshiba may be turned to advantage in the long run. It is no secret that Nakasone would like to strengthen US-Japanese military links, through, for example, participation in the US Strategic Defense Initiative (SDI). And Nakasone has already suggested increased collaboration in anti-submarine warfare activities following the Toshiba case.

David Swinbanks \& Alun Anderson

\section{Indian government cancels contract with US company}

\section{New Delhi}

UNDER pressure from scientists, the Indian government last month took the unusual step of cancelling a multi-million dollar contract with the Hemlock Corporation of the United States for the manufacture of silicon. Under the contract signed in May 1984 with the Department of Electronics (DOE), the US company was to supply technology and equipment for setting up a \$100-million National Silicon Facility (NSF) to produce the 200 tonnes of polysilicon needed annually by the photovoltaic and electronics industry.

The termination of the contract has ended a three-year controversy over the choice of technology for NSF and has been hailed as a triumph of indigenous over imported technology. The step was also unusual because the Indian government had taken great pains to clinch the deal in the first place.

The Hemlock-DOE deal had been hanging fire ever since the contract was signed amid opposition from Indian scientists including Professor C.N.R. Rao, currently chairman of the Scientific Advisory Committee to Prime Minister Rajiv Gandhi. Critics had alleged that in awarding the contract to the company, the DOE had ignored the indigenous technology for making silicon developed by scientists of the Indian Institute of Science (IIS) in Bangalore. In fact the IIS process was being used to make silicon in a 2.5-tonne capacity pilot plant at Mettur Chemicals, a private company. Despite an assurance by IIS and the company that it would be able to scale up the plant capacity at a fraction of the money charged by Hemlock, DOE had sought foreign collaboration with the approval of the then Prime Minister, Mrs Indira Gandhi. The reason, according to DOE, was that silicon produced by Mettur Chemicals was expensive and that its quality did not match that of silicon produced by the Hemlock process.

No other foreign collaboration had attracted so much criticism and the silicon deal with Hemlock became a test case in the continuing controversy over imported versus indigenous technology. Mr Rajiv Gandhi, soon after he became prime minister, was under pressure from some of his advisers to review the agreement with Hemlock. On his personal intervention, the DOE gave Mettur Chemicals a year to expand its capacity to 25 tonnes and to demonstrate the purity of the silicon it produced. The company fulfilled both conditions in March 1986.

K.S. Jayaraman 